\title{
Growth and sediment disturbances of Caulerpa spp. (Chlorophyta) in a submarine canyon
}

\author{
S. L. Williams ${ }^{1 *}$, V. A. Breda ${ }^{1}$, T. W. Anderson ${ }^{2}$ and B. B. Nyden ${ }^{3}$ \\ ${ }^{1}$ Marine Sciences Research Center, State University of New York, Stony Brook, New York 11794, USA \\ ${ }^{2}$ Moss Landing Marine Laboratories, P.O. Box 223, Moss Landing, California 95039, USA \\ ${ }^{3}$ NOAA's National Undersea Research Program, West Indies Laboratory, Teague Bay, Christiansted, St. Croix, US Virgin \\ Islands 00820
}

\begin{abstract}
Growth rates of 7 species of Caulerpa were measured in situ at depths of $20 \mathrm{~m}$ in Salt River canyon, St. Croix, US Virgin Islands. Mean stolon elongation rate for all species of Caulerpa studied was approximately $1 \mathrm{~cm} \mathrm{~d}^{-1}$. Dry biomass accumulated in this new growth was less than $10 \mathrm{mg} \mathrm{d}^{-1}$, and specific growth rates were less than $10 \% \mathrm{~d}^{-1}$; these values are low compared to rates of many benthic macroalgae. Macrofauna (conchs, ghost shrimp, hermit crabs, urchins, rays) were observed disturbing sediment. Plants were uprooted or buried by animals that foraged, burrowed, and made excavations or sediment mounds. Plants experimentally uprooted or buried to simulate effects of animal activities had significantly lower stolon elongation, biomass accumulation, and specific growth rates than control plants. We hypothesize that the productivity of these algae is limited in part by animal-mediated sediment disturbances.
\end{abstract}

\section{INTRODUCTION}

The green coenocytic macroalgae Caulerpaspp. are common inhabitants of soft and hard bottoms in tropical and subtropical regions. Caulerpa spp. are important as colonizers in seagrass bed succession, in part because they help stabilize sediments with their rhizoids (Den Hartog, 1977; Williams, 1981). Soft bottom habitats are subjected to sediment disturbances by both physical (e.g. surge) and biological (macrofauna activities) processes. Marine animal-sediment interactions have been investigated (e.g. Ginsberg and Low enstam, 1958; Rhoads and Young, 1970; Aller and Dodge; 1974), but their effects on plant communities have received little consideration (Suchanek, 1983). Related studies on the effects of sedimentation on macroalgae have concluded that sediment disturbances exert considerable control over the structure of these communities (Daly and Mathieson, 1977;

\footnotetext{
- Present address and addressee for reprint requests: NOAA/ NURP. West Indies Laboratory, Teague Bay, Christiansted, St. Croix, US Virgin Islands 00820

Contribution \#441 from Marine Sciences Research Center, \#131 from West Indies Laboratory, and \#1 from NURP
}

Devinny and Volse, 1978; Hay, 1981; Taylor and Littler 1982).

Initial observations made on the sand floor of Salt River submarine canyon, St. Croix, US Virgin Islands $\left(1747^{\prime} \mathrm{N} ; 6445^{\prime} \mathrm{W}\right.$ ) provided the impetus for this investigation. We recognized two major types of sediment disturbances which could affect the growth of Caulerpa spp. in the canyon. First, stolons and rhizoids were uprooted by surge, burrowing activities of deposit-feeding echinoids such as Meoma ventricosa, or excavations of rays. Second, plants could be buried by physically-created sediment movements, the activities of bottom-feeding macrofauna and callianàssid shrimps, which erect volcano-like mounds and spew out large quantities of sediment. Activities of animals mentioned above have been described (Ogden, 1980; Scheibling, 1982; Suchanek, 1983)

The objective of this research was to determine the effect of uprooting and burial on the growth of Caulerpa spp. To accomplish this, we determined in situ growth rates of Caulerpa spp. growing on the canyon floor and compared these with experimentally uprooted and buried plants. We also identified and determined the relative importance of macrofauna which disturb the sediment. 


\section{METHODS}

This study was conducted during a 1 wk mission in April 1983 at NOAA's National Undersea Research Program at West Indies Laboratory, Fairleigh Dickinson University. This site was revisited in December 1983 for additional sampling. The program operates 'Hydrolab', an underwater laboratory and saturation diving facility. Use of 'Hydrolab' enabled us to gather data that had proven difficult to obtain in shallower areas of St. Croix waters due to boating activities, lack of adequate Caulerpa populations, and turbid water.

Growth measurements. All Caulerpa thalli within a $9 \mathrm{~m}$ radius from a fixed reference point at $20 \mathrm{~m}$ depth were identified. Apical growing points of individual stolons and branches were marked by placing numbered reference flags in the sediment next to the apex. New growth was measured as cm of stolon extending beyond the reference flag. Notes were made on necrosis or death of the thalli. At the end of $6 \mathrm{~d}$, a haphazardly selected subset of plants was collected for dry weight determinations. Old growth was severed from new at the point of the reference flag; each portion was placed in a labelled plastic bag, returned to the surface, and frozen. After $2 \mathrm{~d}$, these plants were thawed, cleaned of sediments, measured, dried at $90^{\circ} \mathrm{C}$ for $24 \mathrm{~h}$, and weighed. Specific growth rate was calculated as:

$$
\mu=\left(\left(1 \mathrm{n} \mathrm{W}_{1}-1 \mathrm{n} \mathrm{W}_{2}\right) / \mathrm{t}\right) \times 100
$$

where: $W_{1}=g$ dry weight ( $g$ dry) of whole plant including new growth; $\mathrm{W}_{2}=\mathrm{g}$ dry of whole plant minus $g$ dry new growth; $\mathrm{t}=$ days of new growth.

Sediment disturbance experiments. Growth was similarly determined for Caulerpa thalli that were uprooted and buried experimentally. Treated plants were chosen haphazardly from the populations. The apex and adjacent $10 \mathrm{~cm}$ of stolon were uprooted in 30 plants. Other plants were partially covered with sediments, simulating the effects of the ghost shrimp Callianassa rathbunae. Sediment (mean grain size = $0.325 \mathrm{~mm}$ ) was collected from the study site, dried and packaged into doses of $369 \mathrm{~g}$ dry $\left(250 \mathrm{~cm}^{3}\right)$, the average amount ejected daily by $C$. rathbunae in Salt River canyon (Suchanek, 1983). The sediment doses were applied once to the apical region and adjacent stolon of 18 plants and likewise daily to another 14 . At the end of $6 \mathrm{~d}$, plants were uncovered and measured. The daily sediment dosage experiment was repeated at the same site for $7 \mathrm{~d}$ in December 1983 when 20 treated and 20 untreated plants were measured and collected on Day 8.

Macrofauna observations. An attempt was made to determine abundances and activities of animals which could affect the growth of Caulerpa spp. by disturbing sediment. Four permanent belt transects $(30 \times 3 \mathrm{~m})$ were surveyed to the northeast, northwest, southeast, and southwest of the fixed reference point during 4 consecutive days and nights. All animals observed on the transects were counted and their activities noted.

Statistical analyses. One-way ANOVA's were used to test for significant differences in growth data, first using Bartlett's test for homogeneity of variance (Sokal and Rohlf, 1969). Growth data with nonhomogeneous variances were log transformed. Means are reported as untransformed values. Confidence limits are reported as back-transformed values and thus, are asymmetrical. A posteriori comparisons among stolon elongation rates were made using a sum of squares simultaneous test procedure (Sokal and Rohlf, 1969). A log-likelihood test (G statistic) was used to assess differences other than growth rates in the April sediment disturbance experiment (Sokal and Rohlf, 1969). A Friedman test extended to several observations per treatment was applied to animal distribution data (Conover, 1971).

\section{RESULTS}

\section{Growth rates}

Most of the seven Caulerpa species identified in the study area grew approximately $1 \mathrm{~cm} \mathrm{~d}^{-1}$ during April (Table 1). There were no significant differences in stolon elongation rates among the different species $(p>0.90)$. New growth contributed an average of less than $10 \mathrm{mg}$ dry biomass $\mathrm{d}^{-1}$ and specific growth rates were less than $10 \% \mathrm{~d}^{-1}$ (Table 1 ). There were no significant differences in specific growth rates among species $(p>0.90)$. Biomass accumulation, however, differed significantly among the species $(p<0.05)$. This difference probably reflects the greater weight of individuals of C. cupressoides $\mathrm{v}$. lycopodium f. elegans ( $2 \mathrm{~g}$ dry individual ${ }^{-1}$ ) in contrast to the other species (1 $\mathrm{g}$ dry indiv. ${ }^{-1}$ ).

\section{Sediment disturbance effects}

Growth rates in experimentally disturbed (i.e uprooted or covered with sediments once or daily) Caulerpa sertulariodes and $C$. cupressoides v. lycopodium f. elegans differed significantly from untreated plants $(\mathrm{p}<0.01)$ in the April experiment (Table 2). Only a few individuals of other species were disturbed and thus not included in the results. Daily burial reduced stolon elongation significantly more than burial once or uprooting $(\mathrm{p}<0.05)$. Growth of uprooted C. cupressoides v. lycopodium f. elegans did not differ significantly from uprooted $C$. sertulariodes $(p>0.90)$ however the former species grew signifi- 
Table 1 Relative abundances and growth rates of undisturbed Caulerpa spp., April 1983. Mean values (95\% confidence interval), $n=$ sample size. Mean exclude nongrowing plants. Dashes indicate no data

\begin{tabular}{|c|c|c|c|c|c|c|c|}
\hline \multirow[t]{2}{*}{ Species } & \multirow[t]{2}{*}{$\begin{array}{l}\% \text { Total no. } \\
\text { plants }\end{array}$} & \multirow{2}{*}{$\begin{array}{l}\text { Stolon } \\
\text { elongation } \\
\mathrm{cm} \mathrm{d}^{-1}\end{array}$} & \multirow[b]{2}{*}{$\mathbf{n}$} & \multicolumn{2}{|c|}{$\begin{array}{l}\text { Biomass } \\
\text { accumulation }\end{array}$} & \multicolumn{2}{|l|}{$\begin{array}{l}\text { Specific } \\
\text { growth }\end{array}$} \\
\hline & & & & $m g$ dry $d^{-1}$ & $\mathrm{n}$ & $\% \mathrm{~d}^{-1}$ & $\mathrm{n}$ \\
\hline C. sertulariodes & 51 & $1.6(0.93-1.92)$ & 84 & $1.43(0.00-7.78)$ & 21 & $7.17(1.75-20.16)$ & 21 \\
\hline $\begin{array}{l}\text { C. cupressoides v. lycopodium } \\
\text { f. elegans }\end{array}$ & 31 & $1.8(0.22-7.51)$ & 45 & $0.35(0.02-0.76)$ & 15 & $7.38(0.66-13.68)$ & 15 \\
\hline C. mexicana & 9 & $1.0(0.26-2.48)$ & 8 & $0.23(0.00-2.60)$ & 4 & $2.04(0.14-35.58)$ & 4 \\
\hline C. cupressoides v. flabellata & 4 & $1.0(0.09-8.81)$ & 13 & - & & - & \\
\hline C. cupressoides & 3 & $0.8(0.12-4.93)$ & 6 & $0.28(0.00-0.76)$ & 4 & $7.62(0.33-84.37)$ & 4 \\
\hline C. prolifera & 2 & $0.4(0.09-5.11)$ & 5 & - & & - & \\
\hline C. taxifolia & $<1$ & $0.0(0.00)$ & 2 & - & & - & \\
\hline
\end{tabular}

Table 2. Effects of experimental sediment disturbances on stolon elongation rates of Caulerpa sertulariodes and C. cupressaides v. lycopodium f. elegans, April $1983 . \overline{\mathrm{X}}=\mathrm{cm} \mathrm{d}^{-1} ; \mathrm{n}=$ sample size; $\mathrm{CI}=95 \%$ confidence interval

\begin{tabular}{|c|c|c|c|c|c|c|}
\hline \multirow[t]{2}{*}{ Treatment } & \multicolumn{3}{|c|}{ All plants } & \multicolumn{3}{|c|}{ Excluding non-growing plants } \\
\hline & $\mathrm{n}$ & $\overline{\mathrm{X}}$ & $\mathrm{CI}$ & $\mathrm{n}$ & $\overline{\mathrm{X}}$ & $\mathrm{CI}$ \\
\hline Control & 153 & 1.4 & $1.0-1.5$ & 129 & 1.7 & $1.2-1.8$ \\
\hline Uprooted & 29 & 1.5 & $1.0-1.6$ & 28 & 1.5 & $1.1-1.7$ \\
\hline Sediments applied: once & 15 & 1.0 & $0.0-4.9$ & 9 & 1.3 & $0.9-1.6$ \\
\hline daily $(5 \mathrm{~d})$ & 14 & 0.8 & $0.2-1.1$ & 9 & 1.3 & $0.4-1.9$ \\
\hline
\end{tabular}

Table 3. Effects of experimental sediment disturbances on Caulerpa sertulariodes and C. cupressoides v. Iycopodium f. elegans, April 1983. Sample size $=n$

\begin{tabular}{|c|c|c|c|c|}
\hline Treatment & $\mathrm{n}$ & Zero growth & $\begin{array}{c}\% \text { of } n \\
\text { Partially decomposed }\end{array}$ & Dead * \\
\hline Control & 153 & 16 & 7 & 3 \\
\hline Uprooted & 29 & 3 & 17 & 0 \\
\hline Sediments applied: once & 15 & 40 & 35 & 6 \\
\hline daily & 14 & 36 & 14 & 7 \\
\hline \multicolumn{5}{|c|}{ - Includes growing and nongrowing plants } \\
\hline
\end{tabular}

cantly less than $C$. sertularoides $(p<0.005$ ) when both were buried. The proportion of plants which were partially decomposed, did not grow, or died was higher in the experimentally disturbed than in the undisturbed plants ( $p<0.005$; Table 3 ). Some plants having partially decomposed thalli grew and some apparently healthy thalli did not grow. The significant differences in growth rates mentioned above included the increased proportion of non-growing plants. In order to ascertain whether disturbed individuals grew more slowly than undisturbed ones, the non-growers were eliminated from the data set. In this case, the mean growth rate of disturbed plants was numerically lower but not statistically different than undisturbed ones.
This result confirmed our observations that certain individuals did not appear to be affected during the disturbances.

Many individuals of Caulerpa spp. responded rapidly to the sediment disturbances. Uprooted plants appeared healthiest. Uprooted stolons reattached to sand by growth of new rhizoids usually within $3 \mathrm{~d}$. Rhizoids of the uprooted portion did not reattach to sediments. Some of the buried upright blades differentiated into a new stolon or produced a new upright (Fig. 1). Most plants which were completely buried were green when uncovered and had grown. Within $2 \mathrm{~d}$ growing apices of buried plants had turned up. often extending through the sediment mound. Plant 


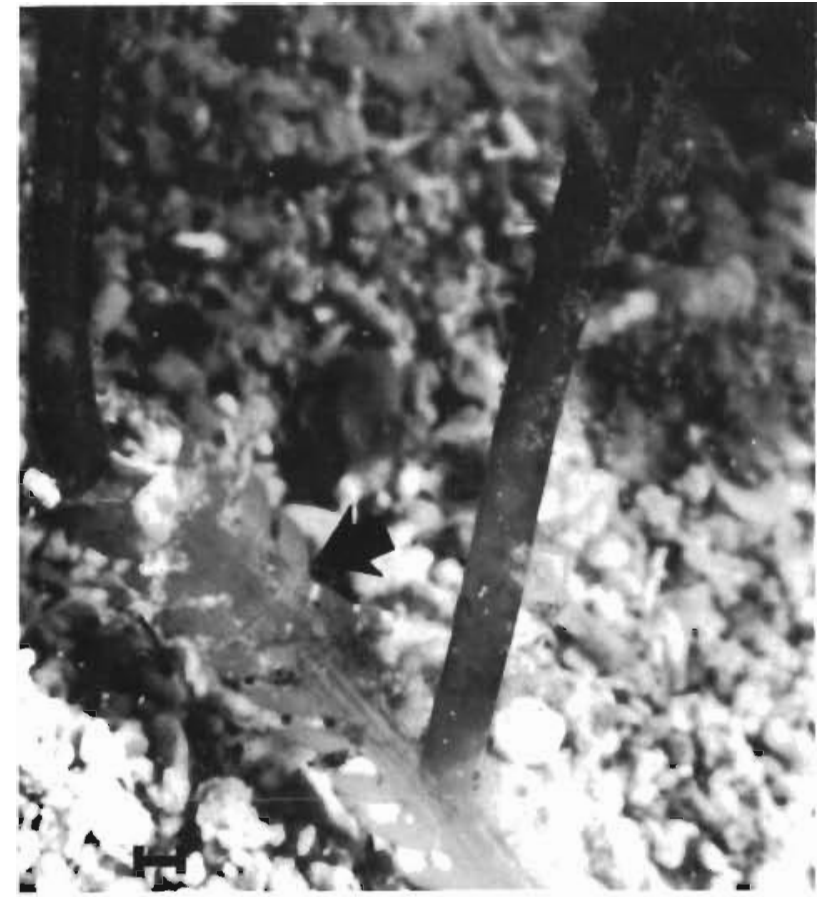

Fig. 1. Caulerpa cupressoides v. lycopodium f. elegans Arrow: buried upright blade which initiated 2 new uprights. Scale $=1 \mathrm{~mm}$

growth essentially kept pace with the rate of experimental sedimentation, which delivered $369 \mathrm{~g}$ dry to an area of about $79 \mathrm{~cm}^{2}$ and typically $30 \mathrm{~cm}$ of stolon.

Daily observation of all plants enabled a rough estimation of the frequency of natural sediment disturbances. Of the control plants, $11 \%(n=201)$ were broken, uprooted, or at least partially buried by Callianassa mounds. Of these disturbed plants, $52 \%$ (controls: $6 \%$ ) exhibited partial decomposition associated with the site of disturbance, zero growth, or death. These percentage values are conservative; there was an approximately equal number of questionable disturbances.

Because of disparate sample sizes and lack of information on other growth parameters such as biomass accumulation, the daily sediment application experiment was repeated in December on the most common species, Caulerpa sertulariodes. Treated plants had significantly lower mean stolon elongation $(p<0.01)$, biomass accumulation ( $p<0.05$ ), and specific growth rates $(p<0.001)$ than controls (Table 4$)$. When nongrowers were excluded from the data, stolon elongation and specific growth rates were different between treated and control plants $(p<0.05)$ although biomass accumulation was not. Nine control and 11 treated plants of the original 20 marked of each type could not be recovered. The plants or flags had disappeared or the flags were obviously moved by heavy surge and movement of sediment ridges. In April, when seas
Table 4 Growth of sediment-treated Caulerpa sertulariodes, December 1983, including non-growing plants. Mean values (95\% confidence interval). Sample size $=n^{*}$

\begin{tabular}{|lcc|}
\hline \multicolumn{1}{|c}{ Parameter } & $\begin{array}{c}\text { Controls } \\
\text { (no sediments) } \\
(\mathrm{n}=11)\end{array}$ & $\begin{array}{c}\text { Sediments } \\
\text { applied daily } \\
\text { for } 7 \mathrm{~d} \\
(\mathrm{n}=9)\end{array}$ \\
\hline $\begin{array}{l}\text { Stolon elongation } \\
\left(\mathrm{cm} \mathrm{d}^{-1}\right)\end{array}$ & $1.23(1.13-1.58)$ & $0.53(0.27-0.98)$ \\
$\begin{array}{l}\text { Biomass accumulation } \\
\left(\mathrm{mg} \mathrm{d}^{-1}\right)\end{array}$ & $3.44(1.58-4.63)$ & $1.59(0.20-2.11)$ \\
$\begin{array}{l}\text { Specific growth rate } \\
\left(\% \mathrm{~d}^{-1}\right)\end{array}$ & $1.38(1.10-3.47)$ & $0.46(0.01-1.77)$ \\
Zero growth (\% n) & 0 & \multicolumn{2}{c}{22} \\
$\cdot$ Number of original 20 marked that were measureable
\end{tabular}

where much calmer, only 3 plants had disappeared and 1 flag had moved of the original 263.

\section{Macrofauna and effects on Caulerpa}

Thirteen species of animals were classified according to the nature of their disturbance of the sediment (Table 5). Major disturbers uprooted plants, excavated holes which broke or undermined plants, trampled plants, or caused large-scale sediment redistributions affecting at least a $0.25 \mathrm{~m}^{2}$ area or $5 \mathrm{~cm}$ of sediment depth. These included all taxa with densities greater than one per $360 \mathrm{~m}^{2}$ (area covered by 4 transects). Minor disturbers were estimated to have minimal effects on Caulerpa spp. They caused only the top 1 to $3 \mathrm{~cm}$ of sediment to be redistributed during feeding activities (peacock flounder Bothus lunatus, flying gurnard Dactylopterus volitans) or grazed on Caulerpa spp. or associated biota (Bermuda chub Kyphosus sectratrix, French angelfish Pomacanthus paru).

There were no significant differences in frequencies of occurrence of each major disturber (Callianassa rathbunae not tested) among the 4 transects or between day and night ( $p>0.90$ ). Accordingly, counts were combined from all 4 transects per sampling period to yield densities (Table 5). Strombus gigas (conch) and Meoma ventricosa (heart urchins) were the most frequently encountered disturbers.

Ghost shrimp Callianassa rathbunare and rays Dasyatis americana caused the greatest sediment disturbance. The activities and densities of ghost shrimp in Salt River canyon have been described by Suchanek (1983). Rays continually disturbed the bottom, creating sediment plumes up to $1 \mathrm{~m}$ from the site of their activity. Frequently they left 1 to 2 cylindrical excavation 
Table 5. Animals observed on Salt river canyon floor, grouped according to their effect on Caulerpa spp. Mean densities \pm 1 standard deviation, $n=8$ surveys

\begin{tabular}{|c|c|}
\hline Major disturbers & $\#(360 \mathrm{~m})^{-}$ \\
\hline \multicolumn{2}{|l|}{ Mollusca } \\
\hline Strombas gigas (conch) & $5 \pm 3$ \\
\hline \multicolumn{2}{|l|}{ Crustacea } \\
\hline Callianassa rathbunae (ghost shrimp) ${ }^{*}$ & $1 \pm 1$ \\
\hline Petrochirus diogenes (conch hermit crab) & $1 \pm 2$ \\
\hline \multicolumn{2}{|l|}{ Echinodermata } \\
\hline Meoma ventricosa (heart urchin) & $4 \pm 3$ \\
\hline \multicolumn{2}{|l|}{ Chordata } \\
\hline Dasyatis americana (southern stingray) & $1 \pm 1$ \\
\hline \multicolumn{2}{|l|}{ Minor disturbers } \\
\hline \multicolumn{2}{|l|}{ Mollusca } \\
\hline Natica canrena (colorful moon snail) & - \\
\hline \multicolumn{2}{|l|}{ Chordata } \\
\hline Dactylopterus volitans (flying gurnard) ${ }^{\cdot}$ & - \\
\hline Pomacanthus paru (French angelfish) ${ }^{\cdots}$ & - \\
\hline Bothus lunatus (peacock flounder) & 1 \\
\hline \multicolumn{2}{|l|}{ Others (effect unknown) } \\
\hline \multicolumn{2}{|l|}{ Crustacea } \\
\hline Decapoda (shrimp) & 1 \\
\hline \multicolumn{2}{|l|}{ Echinodermata } \\
\hline Tripnuestes esculentus (urchin) & 1 \\
\hline \multicolumn{2}{|l|}{ Chordata } \\
\hline Caranx ruber (bar jack) & 1 \\
\hline Kyphosus sectarix (Bermuda chub) & 1 \\
\hline $\begin{array}{l}\text { - Only sediment mounds seen on transects. } \\
\text { from Suchanek (1983) } \\
\text {. Not found on transects }\end{array}$ & Densities \\
\hline
\end{tabular}

holes $(8 \mathrm{~cm}$ wide $\times 10 \mathrm{~cm}$ deep). Large depressions ( $1 \mathrm{~m}$ wide $\times 20 \mathrm{~cm}$ deep) on the bottom with Caulerpa undermined at the edges frequently were noted and were assumed to be the result of buried rays. Heart urchins Meoma ventricosa uprooted Caulerpa and produced sediment ridges $(3 \mathrm{~cm}$ high $\times 2 \mathrm{~cm}$ wide) on both sides of their paths. Conch Strombus gigas and hermit crabs Petrochirus diogenes inhabited large heavy shells which they dragged over and rested on the vegetation. Conch were found in shell-sized depressions up to $7 \mathrm{~cm}$ deep. Hermit crabs actively excavated shell-sized depressions up to $10 \mathrm{~cm}$ deep.

\section{DISCUSSION}

The sediment disturbance experiments were superimposed on natural disturbances since all plants were unprotected from surge or macrofaunal activities. Surge was greater in December than April and created sediment ridges $18 \mathrm{~cm}$ high by $28 \mathrm{~cm}$ wide. This increase perhaps accounted for the difference in the results from the two disturbance experiments. Another contributing factor may be that the daily sedimentation treatment continued an additional two days in December. In April, the growing plants in disturbed and control populations were not significantly different. In December, mean growth rates for the disturbed population were significantly lower than controls as a result of both an increased proportion of non-growers and lower growth rates. At this time, almost one-third of the plants had their stolon apices uprooted during the experiment and several had damaged apices. The difference in the 2 experiments cannot be attributed to deletion of 1 species in the December experiment (see 'Results').

Sedimentation decreased the growth of Caulerpa spp. more than uprooting. This suggests that the activities of heart urchins have minor effects on Caulerpa spp. compared to those of rays and callianassid shrimps. Similarly, the effects of a one-time heavy sedimentation were less severe than chronic sedimentation (e.g. Callianassa mounds). A seasonal pattern to sediment disturbance effects in Salt River canyon may occur if surge in winter augments the effects of macrofauna.

The ability of Caulerpa spp. to survive sediment disturbances is probably related to many generic factors. Our findings confirmed the observation that thallus differentiation is very plastic (Jacobs, 1964, 1970). Buried thalli develop new growing apices that can differentiate into stolons or upright blades (Fig. 1). The apices grow turned up, thus away from a sediment mound. Caulerpa spp. also have a remarkable healing response to wounding (Dawes and Goddard, 1978), which would serve to minimize frequently observed mechanical damage. Finally, chloroplasts move into the uncovered portions of partially buried coenocytic thalli (Williams, pers. obs.), possibly maximizing productivity

The energetic cost of partial burial may be reflected in the lower biomass accumulation and specific growth rates. Burial involves respiration of the buried portions, movement of chloroplasts away from, and photosynthate to, those portions, and a possible reduction of photosynthetic area. The pattern of Caulerpa spp. growth, i.e. rapid stolon elongation with very little biomass invested, perhaps serves to ensure 'escape' from a sediment disturbance at minimal cost.

Soft unconsolidated sediment habitats such as Salt River canyon are subjected to frequent disturbances in the form of sediment redistribution from storm, surge, and bioturbation. Sediment disturbances were found to limit the productivity of the seagrass Thalassia testudinum on a similar substratum (Suchanek, 1983). We have shown that biomass accumulation, specific growth rates and the number of growing Caulerpa plants were decreased by sediment disturbances, serv- 
ing to reduce productivity of these algae. The magnitude and frequency of natural sediment disturbances are needed to evaluate fully the impact on Caulerpa productivity. Without measuring these directly, we feel natural sediment disturbances exert a major effect on the populations, given our estimate that at least $6 \%$ of the control population was impacted within $6 \mathrm{~d}$ and our ongoing observations. The productivity of Caulerpa spp. in Salt River canyon was estimated to be 1-7 mg dry $\mathrm{m}^{-2} \mathrm{~d}^{-1}$, using the average plant density of $0.8 \mathrm{~m}^{-2}$. This rate can be converted to 0.3 to $1.0 \mathrm{mg}$ $\mathrm{C} \mathrm{m}^{-2} \mathrm{~d}^{-1}$, assuming a carbon content of $27 \%$ dry weight (Williams, 1984). This productivity is very low compared to that of many hard bottom macroalgae (e. $\mathrm{g}$. Mann, 1973; DeBoer et al., 1978; Rogers and Salesky, 1981; Gerard, 1982). Caulerpa spp. productivity in Salt River canyon is apparently not low due to factors intrinsic to the canyon. Mean stolon elongation rates found for most Caulerpa spp. growing there were higher than maximum rates previously reported (Chen and Jacobs 1966, 1968; Mishra and Kefford, 1969; O'Neal and Prince, 1982) and similar to rates from shallower ( 1 to $5 \mathrm{~m}$ ) population on St. Croix (Williams, unpubl.). Compared to Salt River canyon, higher biomass on certain hard bottoms contributes to their higher productivity, but higher specific growth rates also contribute. For example, coral-reef algae typically have low biomass but high areal productivity (Carpenter, 1984). This comparison reinforces the suggestion that sediment disturbances cause a major difference not only in the structure but function of primary producers in each type of bottom.

Acknowledgements. The success and safety of Mission \#83-5 were due to the efforts of the Hydrolab staff (D. Anderson, R. Campagna, H. Carpenter, R. Rounds, W. and J. Schane) and to the support divers (M. Lorang, R. Runquist, H. Simon), to whom we are most grateful. $M$. Lorang performed grain size analysis. The comments of 2 anonymous reviewers and of $M$. Fonseca, Drs. V. Gerard and C. Kitting were appreciated. This research was supported by NOAA grant \#NA83AAAO1273, from the Underseas Research Program

\section{LITERATURE CITED}

Aller, R. C., Dodge, R. E. (1974). Animal-sediment relations in a tropical lagoon Discovery Bay, Jamaica. J. mar. Res. 32: 209-232

Carpenter, R. C. (1984). Herbivores and herbivory on coral reefs: effects on algal community biomass, structure, and productivity. Ph. D. dissertation, University of Georgia, Athens

Chen, J. C. W., Jacobs, W. P. (1966). Quantitative study of development of the giant coenotyte, Caulerpa prolifera Am. J. Bot. 53: 413-423

Chen, J. W. C., Jacobs, W. P. (1968). The initiation and elongation of rhizoid clusters in Caulerpa prolifera. Am. J. Bot. 55: $12-19$
Conover, W. J. (1971). Practical nonparametric statistics Wiley, New York

Daly, M. A., Mathieson, A. C. (1977). The effects of sand movement on intertidal seaweeds and selected invertebrates at Bound Rock. New Hampshire, USA. Mar Biol 43: 45-55

Dawes, C. J., Goddard, R. H. (1978). Chemical composition of the wound plug and entire plants for species of the coenocytic green alga, Caulerpa. J. exp. mar Biol. Ecol 35: $259-263$

DeBoer, J. A., Guigli, H. J., Israel, T L., D'Elia, C. F. (1978) Nutritional studies of two red algae. I. Growth rate as a function of nitrogen source and concentrations. J. Phycol. 14: $261-266$

Den Hartog, C. (1977). Structure, function, and classification in seagrass communities. In: McRoy, C. P., Helfferich, C. (ed.) Seagrass ecosystems: a scientific perspective. M Dekker, New York, p. 89-121

Devinny, J. S., Volse, L. A. (1978). Effects of sediments on the development of Macrocystis pyrifera gametophytes. Mar. Biol. 48: 343-348

Gerard, V A. (1982). Growth and utilization of internal nitrogen reserves by the giant kelp Macrocystis pyrifera in a low-nitrogen environments. Mar. Biol. 66: 27-35

Ginsberg, R. N., Lowenstam, H. A. (1958). The influence of marine bottom communities on the depositional environment of sediments. J. Geol. 66: 310-318

Hay, M. E. (1981). The functional morphology of turf-forming seaweeds: persistence in stressful marine habitats. Ecology 62: 739-750

Jacobs, W. P. (1964). Rhizoids-production and regeneration of Caulerpa prolifera. Publ. Sta. Zool. Napoli 43: 185-196

Jacobs, W P. (1970). Development and regeneration of the algal giant coenocyte Caulerpa. In: Frederick, J. F., Klein, R. M. (ed.) Phylogenesis and morphogenesis in the algae. Ann. N.Y. Acad. Sci. 175: 732-748

Mann, K. H. (1973). Seaweeds: their productivity and strategy for growth. Science 182: 975-981

Mishra, A. K., Kefford, N. P. (1969). Developmental studies on the coenocytic alga, Caulerpa sertularoides. J. Phycol. 5: 103-109

O'Neal, S. W., Prince, J. S. (1982). Relationship between seasonal growth, photosynthetic production and apex mortality of Caulerpa paspaloides (Chlorophyta). Mar. Biol. 72: 61-67

Ogden, J. C. (1980). Faunal relationships in Caribbean seagrass beds. In: Phillips, R. C., McRoy, C. P. (ed.) Handbook of seagrass biology: an ecosystem perspective. Garland STPM Press, New York, p. 173-198

Rhoads, D. C., Young, D. K. (1970). The influence of depositfeeding organisms on sediment stability and community trophic structure. J. mar. Res. 28: 150-178

Rogers, C. S., Salesky, N. H. (1981). Productivity of Acropora palmata (Lamarck), macroscopic algae, and algal turf from Tague Bay reef, St. Croix, U.S. Virgin Islands. J. exp. mar Biol. Ecol. 49: 179-187

Scheibling, R. E. (1982). Habitat utilization and bioturbation in Oreaster reticulata (Asteroidea) and Meoma ventricosa (Echinoidea) in a subtidal sand patch. Bull. mar. Sci. 32 : 624-629

Sokal, R. R., Rohlf, F. J. (1969). Biometry. W. H. Freeman, San Francisco

Suchanek, T. H. (1983). Control of seagrass communities and sediment distribution by Callianassa (Crustacea, Thalassinidea) bioturbation. J. mar Res. 41 281-298

Taylor, P. R., Littler, M. M. (1982). The roles of compensatory mortality, physical disturbance, retention substrate in the 
development and organization of a sand-influenced, rocky-intertidal community. Ecology 63: 135-146

Williams, S. L. (1981). Caulerpa cupressoides: the relationship of the uptake of sediment ammonium and of algal decomposition to seagrass bed colonization. Ph. D. dissertation, University of Maryland, College Park
Williams, S. L. (1984). Decomposition of the tropical macroalga Caulerpa cupressoides (West) C. Agardh: field and laboratory studies. J. exp. mar Biol. Ecol. 80: 109-124

This paper was presented by Dr. G. W. Thayer; it was accepted for printing on October 19, 1984 